S. Afr. J. Agric. Ext.

Vol. 49 No. 3, 2021: 46-61

http://dx.doi.org/10.17159/2413-3221/2021/v49n3a12847
Bakre, Amoo, Garane, \& Ojugbele

(License: CC BY 4.0)

\title{
Achieving the NDP 2030 agricultural agenda in UMzimkhulu: myth or possibility
}

Bakre, R.O. ${ }^{1}$, Amoo, O.T. ${ }^{2}$, Garane, P. ${ }^{3}$ and Ojugbele, H.O. ${ }^{4}$

Corresponding author: M. M. Dlamini. Email: $\underline{\text { Rahmanb@dut.ac.za }}$

\begin{abstract}
The South African Constitution has often been adjudged one of the most progressive constitutions ever written. However, transforming the theoretical content of the Constitution into a reality has proved to be a challenge. Considering that, the NDP 2030 is widely acknowledged as a wellthought-out and structured plan, the converting of the NDP 2030 vision into reality is discussed amongst cynics, who often consider it as an unrealistic vision based on the current circumstances and timeframe. In consonance with the afore-narrative, this paper explores the current circumstances of the Agricultural sector within the UMzimkhulu Municipality and gauges against the agricultural agenda set forth in the NDP 2030. To unravel this nexus, the paper pursues a qualitative approach wherein face-to-face interviews were conducted amongst 63 farmers. Prior to the interview, a pretest was conducted to ascertain the suitability of the instrument. The professional personnel were from the Department of Agriculture and Rural Development; the Department of Water and Sanitation, alongside other key stakeholders within three farming projects in UMzimkhulu, KwaZulu-Natal, Province, South Africa. The conceding view amongst most of the respondents indicated that the agricultural plan outlined in the NDP 2030 was far from attainment considering the current resources, skills, personnel, and timeframe. Thus, the paper advocates several proactive mitigations such as capacitation, tailor-made investments, institutional reinvigoration, and formidable partnerships amidst other practicable recommendations.
\end{abstract}

Keywords: NDP 2030, Capacitation, Agricultural agenda, Rural farming projects

\footnotetext{
${ }^{1}$ Researcher, Department of Public Management, Durban University of Technology, Durban. 41 ML Sultan, Durban, 4001. 074604 7056; Rahmanb@dut.ac.za. Orcid 0000-0001-6487-9729

${ }^{2}$ Research Fellow at Walter Sisulu University: Risk and vulnerability science centre, Mthatha, Private Bag X1

UNITRA, 5117, Tel. 0788466205; E-mail: oamoo@wsu.ac.za. https://orcid.org/0000-0003-1713-3814

${ }^{3}$ Local Agriculture Manager: Agriculture Services, KwaZulu-Natal Department of Agriculture and Rural Development. UMzimkhulu Local Municipality, P/Bag x 527, UMzimkhulu, 3297. Tel. 0392590202;

Email: Phumezile.Garane@kzndard.gov.za. Orcid 0000-0003-3359-3538

${ }^{4}$ Research Fellow at Department of Public Management and Governance, Cape Peninsula University of

Technology, Cape Town, OjugbeleH@cput.ac.za
} 
S. Afr. J. Agric. Ext.

Vol. 49 No. 3, 2021: 46-61

http://dx.doi.org/10.17159/2413-3221/2021/v49n3a12847
Bakre, Amoo, Garane, \& Ojugbele

(License: CC BY 4.0)

\section{INTRODUCTION}

\subsection{Definition of problems: The National Development Plan - Vision 2030}

The South African Constitution has often been adjudged one of the most progressive constitutions ever written (Petersen 2020). However, transforming the theoretical content of the Constitution into practice had always been a challenge. In similitude, the NDP 2030 is widely acknowledged as a well-thought-out and structured plan. However, converting the NDP 2030 vision into reality has always been the discussion amongst cynics such as the Democratic Alliance (DA) who often consider it as an unrealistic vision based on the current circumstances and timeframe. The inception of the National Development Plan (NDP) begun in May 2010 when the former South African President - Jacob Zuma, constituted a 26-man committee to draft a vision and developmental agenda for South Africa. The 26-man committee comprised an advisory body drawn mainly from the private sector. This advisory body was scrupulously selected due to its expertise in specific vital areas (NPC, 2010: 23; NPC, 2011: 24). By June 2011, the committee released a Diagnostic Report outlining the successes and failures since 1994. Two prominent shortcomings identified were the non-implementation of policies as well as the non-inclusion of broad partnerships. These shortcomings were pinpointed as the causative effects of slow progress (NPC, 2011: 24). The 26-man committee consulted widely from the judiciary, financial institutions, unions, religious leaders, local government formations, parliament, state-owned entities, businesses as well as non-profit organisations. These consulted stakeholders provided modifications while offering suggestions on how to enhance the efficacy of this plan. Consequently, in November 2011, the draft national plan was released, which was met with enthusiasm by South Africans from all walks of life (NPC, 2011: 24). However, there were also few critics such as the Congress of South African Trade Union (COSATU), which made several objections regarding the NDP (COSATU, 2013; Zarenda, 2013; Neves and Toit, 2013).

The NPC highlights the following two challenges as the most critical issues facing South Africa too few people work and the standard of education available to the majority is poor (NPC, 2011: 36; Ministry of Economic Development, 2010). Against this background, the NPC aimed to increase the 2010 employment rate from 13 million to 24 million jobs by 2030 (NPC, 2011: 24). Amongst these projected 24 million jobs in 2030, the NPC has allotted 1 million jobs to the

agricultural sector. In consonance to this, the current paper is aimed at exploring the feasibility of achieving these ambitiously projected job opportunities in the agricultural sector. This will, however, be confined to the UMzimkhulu farming communities. The projected 1 million jobs within the agricultural sector were forecasted as a means of providing employment opportunities, reducing poverty and inequality in South Africa. More so, the NPC identified untapped opportunities within the agricultural sector (NPC, 2011). 


\subsection{Hypotheses}

To guide our inquiry into this complexity, the proceeding sections of this paper will discuss the current situation amongst the farming communities of UMzimkhulu; while outlining the nexus between the NDP agricultural agenda with respect to the present situation in UMzimkhulu. Furthermore, it provides an in-depth discussion through the inputs of consulted stakeholders amongst the UMzimkhulu farming community. The discussion herein will critically explore if the 1000000 jobs projected in the agricultural sector are a myth or possibility. Furthermore, the paper will include pragmatic and tailor-made recommendations towards the realisation of 1000000 million sustainable jobs in the agricultural sector by 2030 .

\subsubsection{Current situation in UMzimkhulu}

The UMzimkhulu Municipality covers an estimated landmass of 2436 square metres and is amongst the local municipalities of the Harry Gwala District Municipality, situated in the KwaZulu-Natal Province. This municipality has 22 wards of which are predominantly rural. The UMzimkhulu Municipality is characterised by rural settlements with minimal economic activities and subsistence farming practices (UMzimkhulu Municipality IDP, 2016: 50).

The UMzimkhulu community, like a host of other rural communities of South Africa is yet to benefit from the gains of post-apartheid transformation. A surmountable populace in this community and surrounding environment still suffers the discrepancies and disparities orchestrated by the apartheid regime (Ong'ayo, Onyango and Ochola, 2016 cited by Garane, 2017: 25). The 2011 census estimates the UMzimkhulu populace at 180302 (Statistics South Africa, 2012). Amongst this populace, a majority (90.8 percent) reside in rural communities, while the remaining 9.2 percent are based in semi-rural areas (UMzimkhulu Municipality IDP, 2016: 51). The 15-64 age bracket represents 53.7 percent of the UMzimkhulu populace, while 40.8 percent are below the age of 15 (UMzimkhulu Municipality IDP, 2016: 46). Two parameters can be deduced from these population figures; the 15-64 age bracket suggests the need for employment generation and provision of educational facilities, while the $<15$ group depicts a high dependency ratio. The high dependency rate poses a burden on the guardians who often are unemployed as well as the local government due to its limited funds in providing for social grants (UMzimkhulu Municipality IDP, 2016: 47).

UMzimkhulu Municipality IDP (2016:47) reveals the decline of employment in the agricultural sector from 14 percent in 2001 to 6 percent in 2011. More recent surveys reveal a further reduction in employment in the agricultural sector in UMzimkhulu (UMzimkhulu Municipality IDP, 2016). The above argument creates more skepticism considering the anticipated 1 million jobs in the agricultural sector by 2030. The job declines are not an isolated incidence in the agricultural sector, but a reflection of rural farming amongst a host of other farming communities in KwaZulu-Natal, 
such as Gunjaneni, Mvutshini, Ophondweni, Machi Bini, and Nsolweni (Bakre, 2015: 159; Bakre and Dorasamy, 2017: 70-71). The employment scenario in the KwaZulu-Natal Province is equally synonymous with other agricultural provinces such as the Eastern Cape and Mpumalanga Provinces (Hornby and Cousins, 2016: 8; Manenzhe, Zwane and van Niekerk, 2016: 35; Mabuza, 2014: 35, 88; Khapayi and Celliers, 2016: 3869).

As evidenced by the interviewees, the agricultural sector provides enormous opportunities in this community due to its favourable climatic conditions and arable soil. However, a significant portion of fertile farmland is under-utilised due to - Land-ownership uncertainty and unsettled land claims; Lack of capital; Shortage of skilled labour; and Poor infrastructure (UMzimkhulu Municipality IDP, 2016: 57). Furthermore, several households, particularly those in deep rural areas have access to land for farming practices; however, many of such households have failed to maximize this opportunity (UMzimkhulu Municipality IDP, 2016: 58). Developmental potentials in the agricultural sector have also been identified in the farming of sugar cane, maize, wool, timber, citrus, as well as in poultry, dairy, and beef farming (UMzimkhulu Municipality IDP, 2016: 64). A variety of age-long factors and current technical issues has impeded the realization of these potentials. For instance, the lapses of farming activities in 1986 due to the withdrawal of Farmer Support Services (FSS) in UMzimkhulu still prevails till present day as the Department of Agriculture and Rural Development (DARD) is unable to sustain the support services for farmers (Ong' ayo, Onyango and Ochola, 2016 cited by Garane, 2017: 25).

To revive the agricultural sector in this community, the DARD in UMzimkhulu is currently running some initiatives. One of such is the Izintwala Primary Cooperative Limited (communal estate projects). This project is being funded through a Public-Private Partnership (PPP), which is between the DARD and the Masisizane Fund (a division of Old mutual). The Izintwala Primary Cooperative Limited project is being cultivated on 150 hectares of land and has 75 beneficiaries. Since its inception in 2015, an estimated 1.25 million rands has been invested. Another predominant agricultural initiative in this community is the Sihleza Primary Corporative Limited, which specializes in Soya beans and maize production. The core retrogressions to the progression of these initiatives are illiteracy amongst farmers, poor management, and lack of funds amongst others, which are elaborated in later sections. To address the capacitation shortfall, the PPP introduced training programmes aimed at empowering cooperative members in crop production and financial management.

The features narrated herein are typical of not only the KwaZulu-Natal rural farming communities but also archetypical of those of the Eastern Cape and Mpumalanga Provinces (Hornby and Cousins, 2016: 8; Manenzhe, Zwane and van Niekerk, 2016: 35; Mabuza, 2014: 35, 88; Khapayi and Celliers, 2015: 3869). The above-stated view demonstrates that; these raised concerns contravene the anticipated ' 1 million jobs (in the agricultural sector) as proposed by the NDP. 


\subsubsection{Nexus between NDP and the current situation in UMzimkhulu}

Table 1 provides an insight into the projection made by the NDP concerning its agricultural agenda and makes a comparison with the current situation in UMzimkhulu. Emerged themes were inconsonance with employment and sustainability in the agricultural sector. These themes were selected due to their relatability with the aim of this study.

TABLE 1: Nexus between NDP and the current situation in UMzimkhulu

\begin{tabular}{|c|c|c|c|c|}
\hline Sn & Theme & NDP Target & $\begin{array}{l}\text { Current situation } \\
\text { in UMzimkhulu }\end{array}$ & $\begin{array}{l}\text { Main obstacles to NDP } \\
\text { target }\end{array}$ \\
\hline 1 & $\begin{array}{l}\text { Employment in the } \\
\text { agricultural sector }\end{array}$ & $\begin{array}{l}1000000 \text { jobs by } \\
2030\end{array}$ & $\begin{array}{l}\text { Employment within } \\
\text { the South African } \\
\text { agricultural sector } \\
\text { has declined from } \\
14 \text { percent in } 2001 \\
\text { to } 6 \text { percent in } 2011\end{array}$ & $\begin{array}{l}\text { Institution inertia } \\
\text { Low income } \\
\text { Poor sustainability of } \\
\text { agricultural projects }\end{array}$ \\
\hline 2 & $\begin{array}{l}\text { Better communal } \\
\text { land use }\end{array}$ & $\begin{array}{l}\text { Improve } \text { the } \\
\text { livelihoods of at } \\
\text { least } 370 \quad 000 \\
\text { people through } \\
\text { better communal } \\
\text { land practices }\end{array}$ & $\begin{array}{l}\text { Land issues still } \\
\text { prevail }\end{array}$ & \begin{tabular}{l}
\multicolumn{2}{l}{ Land tenure security } \\
Communal land \\
ownership \\
Land reform acts \\
Literacy
\end{tabular} \\
\hline 3 & $\begin{array}{l}\text { Innovative } \\
\text { market linkages }\end{array}$ & $\begin{array}{l}\text { Boast production } \\
\text { amongst small } \\
\text { scale farmers } \\
\text { Development of } \\
\text { rural road } \\
\text { and rail } \\
\text { infrastructure to } \\
\text { boost agriculture }\end{array}$ & $\begin{array}{l}\text { Some farmers do not } \\
\text { have access to credit } \\
\text { facilities; poor } \\
\text { management of } \\
\text { available funds; } \\
\text { inability to transport } \\
\text { farm products to } \\
\text { market }\end{array}$ & 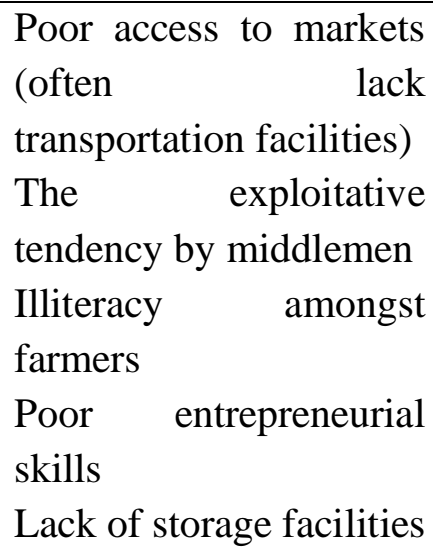 \\
\hline 4 & $\begin{array}{ll}\text { Inclusive rural } \\
\text { development }\end{array}$ & $\begin{array}{l}\text { Inclusive rural } \\
\text { development }\end{array}$ & $\begin{array}{l}\text { A large majority of } \\
\text { the populace in } \\
\text { UMzimkhulu are yet } \\
\text { to be included in the } \\
\text { economic } \\
\text { mainstream }\end{array}$ & $\begin{array}{l}\text { Many farmers are still } \\
\text { excluded from decision } \\
\text { making } \\
\text { Several decisions are } \\
\text { made at the national } \\
\text { level }\end{array}$ \\
\hline
\end{tabular}




\begin{tabular}{|c|c|c|c|c|}
\hline 5 & $\begin{array}{l}\text { Environmental } \\
\text { sustainability }\end{array}$ & $\begin{array}{l}\text { Eco-friendly and } \\
\text { sustainable } \\
\text { environment }\end{array}$ & $\begin{array}{l}\text { Overgrazing of } \\
\text { grassland; } \\
\text { Over-abstraction of } \\
\text { groundwater still } \\
\text { prevails. } \\
\text { In addition, due to } \\
\text { poor farming } \\
\text { practices, the soil } \\
\text { and water have been } \\
\text { degraded. }\end{array}$ & $\begin{array}{l}\text { Overgrazing } \\
\text { grassland } \\
\text { Over-abstraction } \\
\text { groundwater } \\
\begin{array}{l}\text { Poor soil and } \\
\text { management }\end{array}\end{array}$ \\
\hline 6 & $\begin{array}{l}\text { Efficient water } \\
\text { usage }\end{array}$ & $\begin{array}{l}\text { To augment } \\
\text { agricultural } \\
\text { productivity } \\
\text { through water } \\
\text { resource } \\
\text { management }\end{array}$ & $\begin{array}{l}\text { The inefficiency of } \\
\text { water use and } \\
\text { scarcity still prevails }\end{array}$ & $\begin{array}{l}\text { Infrastructural } \\
\text { decadence } \\
\text { Poor practices } \\
\text { Lack of value for water } \\
\text { Poor interaction among } \\
\text { stakeholders } \\
\text { Lack of funds } \\
\text { Lack of technical } \\
\text { expertise } \\
\text { Inadequate } \\
\text { infrastructural } \\
\text { investment } \\
\text { Lack of implementation } \\
\text { of policy }\end{array}$ \\
\hline
\end{tabular}

Extrapolating from the employment decline within the South African agricultural sector from the then 1400000 in 2000, to 876000 jobs in 2016 and 812290 in 2019 (DAFF, 2011; Klein, 2012; den Hartigh, 2016; Luruli, and Mouton, 2016 and Trading Economics, 2019); it is suggestive that the NDP already halfway to its tenure is not inconsonance to the plans of its initiators.

\section{PROCEDURE}

To guide our inquiry into exploring the feasibility of achieving the NDP 2030 Agricultural agenda, a qualitative paradigm was followed. Insights were obtained from provincial personnel from the Department of Water and Sanitation as well as (personnel from the) UMzimkhulu Department of Water and Sanitation. Also included in this study were seasoned agricultural extension workers based in UMzimkhulu. researchers also conducted one-on-one interviews with several coordinators amongst the farmers. Interviews were suspended when responses became repetitive, as saturation was attained. Furthermore, the study involved farmers from three active farming 
projects within UMzimkhulu. These were the Izintwala Primary Co-operative Limited, situated at the uMmisa location in Ward 18; Vusukudla Primary Co-operative Limited at Highland's location in Ward 20; as well as the NMZ Greening Primary Co-operative Limited at the Ndawana location situated in Ward 1. Individual interviews were followed up through Focus Group Discussion (FGD) amongst the farmers within these farming communities. The instrument used was a structured interview which was pretested before the actual data collection. The FGD create a rare privilege to interact with a group of participants to discovering the public thought on a particular subject matter (Morgan, 2013: 13-14; McLafferty, 2004: 189; Dilshad and Latif, 2013; Freitas, Oliveira, Jenkins, and Popjoy, 1998), which is incongruent in the current context. The generated data amongst these interviewees were analysed through thematic analysis. Thematic analysis as described by Nowell, Norris, White, and Moules (2017), involves a process of reading through a data set, whilst identifying patterns in meaning across these data sets. The objective of the one-onone and focus group interviews was to have an insight into stakeholders' perception regarding the feasibility of achieving the NDP 2030 Agricultural agenda in generating an estimated 1 million farming jobs in South Africa by the year 2030. Additionally, questions regarding core challenges impeding the feasibility of this agenda were asked. The discussions were confined to themes such as - Resources at the disposal of farmers; Period to set target; Exogenous and endogenous factors; Capacitation, Funds, and Climatic variations. In total, 74 participants were included. Table 2 provides a summary of the participants involved in this study.

TABLE 2: Summary of Experts consulted

\begin{tabular}{|c|c|c|c|c|}
\hline$S / n$ & Sector & Organisation & Designation & $\begin{array}{l}\text { Number of } \\
\text { interviewees }\end{array}$ \\
\hline 1 & Provincial governance & $\begin{array}{l}\text { Department of } \\
\text { Water and } \\
\text { Sanitation (Durban) }\end{array}$ & $\begin{array}{l}\text { Water Resource } \\
\text { Manager } \\
\text { Deputy }\end{array}$ & 1 \\
\hline 2 & & & $\begin{array}{l}\text { Director: Water } \\
\text { use }\end{array}$ & 1 \\
\hline 3 & Local governance & $\begin{array}{lr}\text { Department of } \\
\text { Water } \\
\text { Sanitation } \\
\text { (UMzimkhulu) }\end{array}$ & Staff 2 & 1 \\
\hline 5 & Local governance & $\begin{array}{l}\text { Department of } \\
\text { Agriculture and } \\
\text { Rural Development } \\
\text { (UMzimkhulu) }\end{array}$ & $\begin{array}{l}\text { Extension } \\
\text { workers }\end{array}$ & 7 \\
\hline
\end{tabular}




\begin{tabular}{|l|l|l|l|l|}
\hline 6 & Rural farmers & $\begin{array}{l}\text { UMzimkhulu } \\
\text { (Izintwala Primary } \\
\text { cooperative) }\end{array}$ & Farmers & 25 \\
\hline 7 & Rural farmers & $\begin{array}{l}\text { Vusukudla Primary } \\
\text { Co-operative } \\
\text { Limited }\end{array}$ & Farmers & 17 \\
\hline 8 & Rural farmers & $\begin{array}{l}\text { NMZ Greening } \\
\text { Primary Co- } \\
\text { operative Limited }\end{array}$ & Farmers & 21 \\
\hline & & $\begin{array}{l}\text { Total number } \\
\text { of participants }\end{array}$ & $\mathbf{7 4}$ \\
\hline
\end{tabular}

\section{FINDINGS}

Though the current study is based among some of UMzimkhulu farming communities, these are not isolated accounts, but a reflection of several farming projects/ communities in KwaZulu-Natal Province and beyond. The findings are thus classified thematically into four broad themes. These are narrated as follows:

\subsection{Capacitation}

Lack of capacitation had been a cogent issue amongst farmers in UMzimkhulu (Garane, 2017). Most notable amongst the incapacitation is the low level of literacy amongst the farmers. This illiteracy has direct and indirect consequences on the sustainability and growth of the farming communities in UMzimkhulu. For instance, their inability to read, grasp or comprehend the content of policy documents often serves as an exclusion to these poor farmers. More so, the farmer's inability to read and write often jeopardises their chances of keeping a sound financial record alongside other required documentation. These views were strongly held by most Extension workers who participated in this study.

\subsection{Resources}

In achieving sustainable and successful rural agricultural initiatives, a tailor-made plan from a tractor to the table should be well synchronized at the inception. However, amongst the UMzimkhulu farming initiatives, several bottlenecks have been identified between the tractors to table course. Predominant concerns include - lack of transportation to transport farm produces to market; inadequate storage facilities; insufficient funds; poor managerial acumen and land rights ownership challenges. The farmers from the Izintwala Primary cooperative had emphasised the issues of transportation and storage facilities, whilst those from Vusukudla Primary Co-operative Limited raised the issue of inadequacy of funds. 
S. Afr. J. Agric. Ext.

Vol. 49 No. 3, 2021: 46-61

http://dx.doi.org/10.17159/2413-3221/2021/v49n3a12847
Bakre, Amoo, Garane, \& Ojugbele

(License: CC BY 4.0)

\subsection{Water-related challenges}

Water shortage has been a domineering and constraining factor in several rural agricultural projects across South Africa (Nephawe, Mwale, Zuwarimwe, and Tjale, 2021). This constraining factor is synonymous with all farming projects in UMzimkhulu. Most of the farming projects are dependent on erratic rainfall and face difficulties in obtaining water permits -, particularly along the UMzimkhulu River. The extension workers reported the concern of water permits as a daunting task. Consequently, this poses an enormous challenge, particularly during the dry winter months. On the contrary, the farmers who use irrigation as a backup often do not possess the technical capacities to maintain this irrigation practice. More so, some farmers did allege that the fuel required for fueling the irrigation machine was far beyond their affordability. Further challenges exacerbating the water concern are hydrological skill shortage, inadequate funds, lack of data, lack of technical and managerial expertise, lack of infrastructure, poor practices, and unsustainable abstraction of groundwater (Department of Water and Sanitation, 2016: 6). The personnel from the Department of Water and Sanitation both at the provincial and local governments both unanimously agreed that the long-aged water-related challenges are yet to be squarely addressed, and thus, remains a setback for some farming communities faced with water scarcity.

\subsection{Communal discord}

Lack of integration amongst the UMzimkhulu farming communities has created many setbacks for these communities. A predominant disintegrating concern has often been the conflict amongst farmers due to their varying ideology and perception of how the farming projects should be run. Money issues have often split these communities regardless of how much loss or gain the farming projects make. Many farmers are of the view that the lack of transparency and greed are potent issues further disintegrating their farming groupings. More so, evidence provided by the farmers supports the claim that 'individual farming projects in their community are more viable and sustainable in comparison to 'communal projects' primarily due to communal discord. This communal discord as mentioned by some extension workers was a contributing factor to farmer's exit from these farming projects.

\section{CONCLUSIONS AND RECOMMENDATIONS}

This section provides a parallel discussion in consonance with the afore-narration regarding factors impeding agricultural sustainability and development amongst the UMzimkhulu farming communities. Most of these recommendations are drawn from farmers of these communities alongside stakeholders. Thus, the paper advocates five pragmatic and tailor-made recommendations for the UMzimkhulu farming communities. 
S. Afr. J. Agric. Ext.

Vol. 49 No. 3, 2021: 46-61

http://dx.doi.org/10.17159/2413-3221/2021/v49n3a12847
Bakre, Amoo, Garane, \& Ojugbele

(License: CC BY 4.0)

\section{i. Introduction of third's Party Farm Managers}

The introduction of third-party farm managers will help the farmers and facilitate capacity developmental programmes for farmers, amongst other functions. In addition, the third-party farm manager can motivate strategic investment by the government in the provision of storage facilities, synchronised research output to induce a more proactive interaction between researchers and farmers wherein challenges are identified. In turn, researchers use their expertise to address such challenges timeously wherein the manager facilitates the use of technology to help reduce literacy challenges. Furthermore, as alluded by extension workers, farmers may be provided with applications that could help them with their financial records based on simple imputation of figures.

\section{ii. $\quad$ Capacitation of Agricultural extension workers}

South African Agricultural extension workers should be exposed to their counterparts in countries such as Brazil, India, Bangladesh, and China where Agricultural Extension services have been proven as one of the agents piloting the developmental agenda in the agricultural sector amongst these respective countries (Pretty and Bharucha, 2015; Prasad, 2019; Bojanic, 2017). To achieve such a feat, the involvement of government at higher levels will no doubt be imperative in facilitating this process. It is recommended that the UMzimkhulu Agricultural extension worker's managerial, negotiation, entrepreneurial, interpersonal, and innovative skills are sharpened through such avenues. More so, this can be a platform to motive the extension workers to become 'Champions' of the respective projects they supervise or manage.

\section{iii. Institutional reinvigoration}

The local government is perceived as the weakest level of governance and the least trusted sphere of government in South Africa by the masses (Vivier and Wentzel, 2013: 239; Garane, 2017). Ironically, this level of governance is closest to the populace as they operate at the grassroots when compared to government at the provincial or national level (Vivier and Wentzel, 2013: 240). This level of distrust and tension at the local government is often due to the services provided, which contravene the masses' expectations. A predominant issue amongst the (rural) local government of South Africa is often the insufficiency of funds to undertake capital-intensive projects and provision of quality services (Sebola, 2015: 12). More so, these local governments are often overwhelmed by a multitude of challenges that often outstretches their resources or capacity. To address local government's multifaceted shortcomings, the presence of government at the national and provincial level need to extend their reach at the grassroots. The above view can be achieved through periodical monitoring, assessment, involvement, and evaluation practices by governments at higher levels as a bid to support, scrutinise, monitor progress while also identifying areas of underperformance. Furthermore, this will imply personnel from the National Department of Rural Development and Land Reform alongside other Agricultural departmental offices both at national and provincial levels will be required to carry out a more rigorous assessment of initiatives at the 
grassroots. The concern of institutional reinvigoration was also underscored by personnel at the UMzimkulu Department of Water and Sanitation as well as those from the Department of Agriculture and Rural Development. Further to the aforementioned discourse, it is imperative to capacitate Councillors alongside other stakeholders at local government. Such capacitation will enhance their capacity in implementing the content of the NDP and the constitution alongside other relevant policies into realisation.

\section{iv. Water resource management}

Declining water resources has motivated governments of the advanced nation to invest heavily in water resource management (WRM). Regrettably, not the same can be said of undeveloped or developing countries who are most in need of such WRM investments (Knuppe, 2011: 72). Water resource management is not only a cost-effective approach that contributes towards the economic prosperity of a nation but also provides an array of opportunities particularly in the agricultural sector (Bhatti, Koike and Nasu, 2012: 1). WRM practices have changed the landscape of farming practices in Israel and China (Mitrani and Blaustein, 2008: 8). Bhatti, Koike, and Nasu (2012) allege that effective WRM can create pathways for sustainability and exponential growth in the agricultural sector. Calzadilla, Zhu, Rehdanz, Tol, and Ringler (2013: 20) further mention that many opportunities are lost due to the non-utilisation of WRM. Mati (2007: 3) indicates, an estimated 38 million hectares of land is available for cultivation in the Eastern and Southern Africa region exemplifies such lost opportunities. Amongst these 38 million ha, only (about) 3 million ha of land is where water resource management is being practiced upon in an area whose full potential is at 18 million ha. Thus, to achieve an effective water management system, an active involvement of experts such as engineers, researchers, policymakers, Investors, Donors, and Councillors will be required wherein the Agricultural Extension workers and farmers take a leading role. Prior to this engagement of stakeholders in accomplishing an effective WRM system, the expertise of WRM will be required in formulating sustainable WRM related policies. Such policies should also be incorporated into the subsequent Integrated Development Plan (IDP) for the UMzimkhulu Municipality, which is currently lacking.

\section{v. Formidable partnership}

Studies conducted amongst farmers within the eastern and southern African region confirm that several farmers are cognizant of some water conservation approaches and technologies. However, these competencies, technicalities, and experiences are unevenly spread across farming communities of these regions, while some are isolated in academic materials (Mati, 2007 cited by Bakre and Dorasamy, 2017: 89). Should all such competencies, technicalities, experiences, and publications be compiled and harnessed, this will be at the betterment of these regions. Furthermore, this paper advocates that rural farming communities such as the UMzimkhulu should collaborate with international agricultural entities and institutions such as the IFAD. More so, the involvement of the private sector has been found wanting amongst many of these rural farming 
communities. The Department of Agriculture and Rural Development could drive such involvement. Such a partnership could create pathways for development in the biotechnology domain where farmers have access to high value crops all year round. In such circumstances, this may also result in the transformation of seasonal employments to all-year-round employment in the agricultural sector.

\section{SUMMARY}

Achieving the agricultural vision outlined in the NDP 2030 will require several proactive and concise measures amongst stakeholders. Like emerging economies such as Brazil, India, and Indonesia that have driven similar pre-employment initiatives within their respective agricultural sector, were met with similar challenges such as insufficiency of resources, climate-related challenges, poor managerial acumen, land rights ownership, amongst other challenges (De Janvry and Sadoulet, 2019; Boettiger, Denis, and Sangh, 2017; Scoones, Amanor, Favareto, and Qi, 2016; Mercure et al., 2019). Thus, this paper highlights the core impediments undermining the potentials of realising this vision. Realising an inclusive rural transformation as championed by this paper through agricultural development, is also a foci point advocated by several rural developmental analysts as well as the 484 pages NDP document. However, the uniqueness of this paper lies in its ability to propose a tailor-made stratagem for the UMzimkhulu farming communities through discussions with prominent stakeholders. More particularly, one that instigates a developmental, sustainable, and viable rural space. Such developmental strategy is one orchestrated to realistically transform the theoretical content of the NDP into practice while increasing agricultural output, realigning the modalities from 'tractor to table', and transforming the defunct subsistence farming practices into structured commercialised farming.

All these mitigations can equally and possibly induce non-farming employment hence contributing to the rural viability of the UMzimkhulu community. This anticipated success or agendum may however only be realised through Interactive participation of highly committed stakeholders, a Private-Foreign partnership, involvement of the IFAD agency, and farmers championing this course. Additionally, the involvement of foreign expertise and donors will be required in aspects such as water resource management, capacity development, and more importantly, infrastructural development. As advocated in the body of this paper, achieving the agricultural agenda set in the NDP 2030 is intended to instigate an Inclusive rural transformation wherein rural communities such as the UMzimkhulu may become beneficiaries of the economic mainstream from which they had been excluded for several decades. However, an Inclusive rural transformation is arguable not an overnight succession. Hence, as an agendum to achieving the agricultural vision set by the NDP 2030, this paper follows a pathway set forth by the IFAD (2016: 22) - Agricultural Development; Rural development; Rural transformation; Inclusive Rural transformation; and Structural transformation. 


\section{REFERENCES}

BAKRE, R.O., 2015. Water resource management for subsistence farming in ward 19 of KwaZuluNatal (online). M.Tech, Durban University of Technology. Retrieved from:http://ir.dut.ac.za/bitstream/handle/10321/1305/BAKRE_2015.pdf?sequence=1\&is Allowed $=\mathrm{y}$.

BAKRE, O. \& DORASAMY, N., 2017. Driving urban-rural migration through investment in water resource management in subsistence farming: the case of Machi-bini. Environmental Economics, 8(1), 66-74. doi:10.21511/ee.08(1).2017.07.

BOETTIGER, S., DENIS, N. \& SANGHVI, S., 2017. Readiness for agricultural transformation. In cp: Successful agricultural transformations: Six core elements of planning and delivery, Mckinsey Centre for Agricultural. Available online: https://www.mckinsey.com/industries/chemicals/ourinsights/successful-agriculturaltransformations-six-core-elements-of-planning-and-delivery

BOJANIC, H.A. 2017. The Rapid Agricultural Development of Brazil in the Last 20 Years. Special Issue on The Brazilian Agri-food Sector, 16(1): 5-10. Available: https://doi.org/10.1111/1746-692X.12143 (Accessed 10 April 2020).

BHATTI, A. KOIKE, T. \& NASU, S. 2012. Water resources management: pathways for sustainable economic growth and poverty eradication. Retrieved from: http://management.kochitech.ac.jp/ssms_papers/sms125687_fd05c295e09d9310bc02c5ae 26225212.pdf..

CALZADILLA, A., ZHU, K.T., REHDANZ, R. S. TOL, J. \& RINGLER, C., 2013. Economywide Impacts of Climate Change on Agriculture in Sub-Saharan Africa. Ecological Economics 93:150-65.

COSATU., 2013. Summary of Critique of the National Development Plan, March 2013 - Draft (Online). Congress of South African Trade Unions. Retrieved from: http://www.cosatu.org.za/docs/discussion/2013/NDPcritiquesummary.pdf.

DAFF., 2011. Trends in the agricultural sector 2011. Retrieved from: http://www.nda.agricza/docs/statsinfo/Trends2011.pdf.

DE JANVRY, A. \& SADOULET, E., 2019. Transforming developing country agriculture: Removing adoption constraints and promoting inclusive value chain development.

DEN HARTIGH, W., 2016: Agriculture-is-still-creating-employment-in-South Africa. Retrieved From: $\quad$ https://www.farmersweekly.co.za/agri-news/south-africa/agriculture-is-stillcreating-employment-in-sa/.

DILSHAD, R.M., \& LATIF, M.I., 2013. Focus Group Interview as a Tool for Qualitative Research: An Analysis; Pakistan Journal of Social Sciences (PJSS). 33 (1): 191-198. 
DWS., 2016. Regional Water Allocation Reform Implementation Plan: Kwazulu-Natal 2013. 2018, Department of Water and Sanitation, Republic of South Africa.

FREITAS, H., OLIVEIRA, M., JENKINS, M. \& POPJOY, O., 1998. The Focus Group, a qualitative research method. ISRC, Merrick School of Business, University of Baltimore (MD, EUA), WP ISRC No. 010298.

GARANE, P 2017. Extension and Advisory Services from an Agricultural Innovation Systems outlook: Evaluating UMzimkhulu Agriculture Co-operatives in KwaZulu-Natal, South Africa. Masters dissertation. University of Free State.

HORNBY, D. \& COUSINS, B., 2016. Rethinking agriculture in South Africa: Constraints and opportunities. Retrieved from: http://www.plaas.org.za/sites/default/files/publications pdf/PLAAS\%20Rethinking\%20Agriculture report.pdf.

IFAD., 2016. Rural development report 2016. Fostering inclusive rural transformation. Retrieved from: https://www.ifad.org/documents/30600024/30604583/RDR_WEB.pdf/c734d0c4fbb1-4507-9b4b-6c432c6f38c3.

KHAPAYI, M. \& CELLIERS, P,R., 2016. Factors limiting and preventing emerging farmers to progress to commercial agricultural farming in the King William's Town area of the Eastern Cape Province, South Africa. South African Journal of Agricultural Extension. 44 (1). http://dx.doi.org/10.17159/2413-3221/2016/v44n1a374.

KLEIN, N., 2012. Real wage, labor productivity, and employment trends in South Africa: A closer look (No. 12-92). International Monetary Fund.

KNUPPE, K., 2011. The Challenges Facing Sustainable and Adaptive Groundwater Management in South Africa. Water SA 37 (1): 67-79. https://doi.org/10.4314/wsa.v37i1.64110.

LURULI, N.M. \& MOUTON, J., 2016. The early history of research funding in South Africa: From the Research Grant Board to the FRD. S Afr J Sci. 2016;112 (5/6), Art. \#2015-0097, 6 pages. http://dx.doi.org/10.17159/ sajs.2016/20150097.

MABUZA, M.E., 2014. Functionality; productivity; and challenges of land redistribution in Ehlanzeni Region of Mpumalanga Province: a case study of Mbombela Local municipality with reference to Lahlamali Community Property Association. Masters dissertation. University of Limpopo.

MANENZHE, T,Z., ZWANE, E,M. \& VAN NIEKERK, J.A., 2016. Factors affecting sustainability of land reform projects in Ehlanzeni district Mpumalanga Province, South Africa. South African Journal Agricultural Extension. 44, 2, 2016: 30 - 41.

MCLAFFERTY, I., 2004. Methodological issues in nursing research. Focus group interviews as a data collecting strategy; School of Nursing and Midwifery, University of Dundee, Ninewells, Dundee, UK 2004 Blackwell Publishing Ltd. Journal of Advanced Nursing, 48(2), 187-194. 
MERCURE, J.F., PAIM, M.A., BOCQUILLON, P., LINDNER, S., SALAS, P., MARTINELLI, P., BERCHIN, I.I., DE ANDRADE GUERRA, J.B., DERANI, C., DE ALBUQUERQUE JUNIOR, C.L. \& RIBEIRO, J.M., 2019. System complexity and policy integration challenges: the Brazilian Energy-Water-Food Nexus. Renewable and Sustainable Energy Reviews, 105, 230-243.

MITRANI, T, A. \& BLAUSTEIN, J., 2008. Government focal point. Institute for desert research, Ben Gurion University, Chairman of Land Development Committee, Jewish National Fund (JNF), Israel.

Morgan, D, L., 2013. Focus groups as qualitative research: Planning and research design for focus groups; SAGE Research Methods. 10.4135/9781412984287.n4.

NEPHAWE, N., MWALE, M. ZUWARIMWE, J. \& TJALE, M.M., 2021. The Impact of WaterRelated Challenges on Rural Communities Food Security Initiatives. Journal of Agribusiness and Rural Development Research, 7(1).

NEVES, D. \& DU TOIT, A., 2013. Rural Livelihoods in South Africa: Complexity, Vulnerability and Differentiation. Journal of Agrarian Change, 13(1), 93-115.

PAUW, K., MCDONALD, S. and PUNT, C., 2007. Agricultural efficiency and welfare in South Africa. Development Southern Africa, 24(2), 309-333.

PETERSEN, S. 2020. Does a dominant party democracy erode constitutional legitimacy? An analysis of the African national congress and the South African constitution. Masters dissertation, University of Cape Town. Available: http://hdl.handle.net/11427/32325 (Accessed 21 August 2020).

PRASAD, R., 2019. Agricultural Sciences in India and Struggle against Famine, Hunger and Malnutrition. $\quad I J H S, \quad 54.3 . \quad$ Available: https://web.archive.org/web/20200208072545id /https://insa.nic.in/writereaddata/UpLoa dedFiles/IJHS/Vol54_3_2019_Art07.pdf (Accessed 12 August 2020).

PRETTY, J. \& BHARUCHA, Z.P., 2015. Integrated Pest Management for Sustainable Intensification of Agriculture in Asia and Africa. Insects. 6(1):152-182. Available: https://doi.org/10.3390/insects6010152 (Accessed 21 July 2020).

REPUBLIC OF SOUTH AFRICA. Ministry of Economic Development., 2010. The new growth path: the framework. Pretoria: Government Printer.

REPUBLIC OF SOUTH AFRICA. Office of the Presidency., 2011. National Development Plan: vision for 2030. Pretoria.

SCOONES, I., AMANOR, K., FAVARETO, A. \& Qi, G., 2016. A new politics of development cooperation? Chinese and Brazilian engagements in African agriculture. World Development, 81, 1-12.

SEBOLA, M.P., 2015. Ed. Local Government Administration in Post-apartheid South Africa: Some Critical Perspectives. $1^{\text {st }}$ ed. Polokwane: Batatlea Publishers (Pty) Ltd. 
S. Afr. J. Agric. Ext.

Vol. 49 No. 3, 2021: 46-61

http://dx.doi.org/10.17159/2413-3221/2021/v49n3a12847
Bakre, Amoo, Garane, \& Ojugbele

(License: CC BY 4.0)

TRADING ECONOMICS, SOUTH AFRICA., 2019. South Africa-Employment In Agriculture (\% of Total Employment): Retrieved from: South Africa - Trading Economics.

UMZIMKHULU LOCAL MUNICIPALITY., 2016. Integrated Development Plan 2016/ 2017. (Online), Available: https://www.umzimkhululm.gov.za/eDocuments/IDP/IDP_2016_2017.pdf.

VIVIER, E. \& WENTZEL, M., 2013: Community Participation and Service Delivery: perceptions among residents in Cape Town. Journal of Public Administration. Available: http://www.hsrc.ac.za/en/research-data/view/6494.

ZARENDA, H., 2013. South Africa's National Development Plan and its implications for regional development. Tralac Working Paper No. D13WP01/2013. Retrieved from: http://paulroos.co.za/wp-content/blogs.dir/12/files/2013/07/D13WP012013-ZarendaSouth-Africas-NDP-and-implications-for-regional-development-20130612-fin.pdf. And https://www.weforum.org/agenda/2016/05/70-of-africans-make-a-living-throughagriculture-and-technology-could-transform-their-world/. 